\title{
Dia Nacional de Combate ao Fumo: um Marco para o Controle do Tabagismo no Brasil
}

Ao longo dos últimos 25 anos, o controle do tabagismo no Brasil tem sido calcado centralmente em medidas educativas e legislativas. E o marco inaugural desse movimento foi a instituiçâo do Dia Nacional de Combate ao Fumo, a primeira contribuiçấo do Congresso Nacional para o controle do tabagismo no Brasil, por meio da Lei Federal $\mathrm{n}^{\circ}$ 7.488, de junho de 1986.

A partir daí, a data 29 de agosto passou a ser comemorada todos os anos pelo Ministério da Saúde. Em 2011, ano do $25^{\circ}$ aniversário da Lei, nada mais apropriado do que apresentar o tema com uma edição especial da Revista Brasileira de Cancerologia (RBC), exclusivamente voltada ao tabagismo. Aqui, o leitor encontrará 11 artigos originais, sendo dois deles de conteúdo histórico; um de opinião; três de revisão e uma resenha. Revista essa que também será produzida em inglês e distribuída na 15 th World Conference on Tobacco or Health, de 20 a 24 de março de 2012, em Cingapura.

Com a Lei 7.488, o Congresso Nacional contribuiu para introduzir na agenda do Estado Brasileiro açóes educativas e debates públicos sobre os graves riscos do tabagismo, até então conduzidos de forma quase heróica por algumas lideranças médicas. Por isso, merece destaque o fato de a Lei ter sido inspirada em um movimento pioneiro, liderado pela Sociedade Médica do Paraná, que, em 29 de agosto de 1980, lançou a Greve do Fumo, em um esforço para alertar a população daquele Estado sobre os graves riscos do tabagismo.

Estamos falando de uma época na qual o ato de fumar ainda era fortemente relacionado a um estilo de vida positivo, na qual a fumaça de cigarros circulava imponente, repleta de glamour, na maior parte dos ambientes sociais. De um período no qual a mídia nacional canalizava, para todos os lares do país, propagandas de cigarros embaladas em poderosas mensagens e imagens de beleza, liberdade e sucesso. E época na qual a pressão econômica das grandes transnacionais de fumo que se instalaram no Brasil inibia discussóes públicas sobre essa temática.

Nesses 25 anos de comemoraçóes no Dia Nacional de Combate ao Fumo, diversas atividades e mensagens como "largue o cigarro correndo", "esporte sem cigarro é mais radical" e "arte sem cigarro é show" certamente contribuíram para desconstruir no imaginário coletivo as fortes associaçôes entre cigarro e esportes e/ou cigarro e cultura criadas nas propagandas do produto - uma estratégia que até hoje a indústria do tabaco tenta manter para atrair os jovens para o tabagismo.

Ao criar a Lei Federal no 7.488, o Congresso Nacional brindou o país com uma importante ferramenta de educação e comunicação, que hoje se traduz em uma ampla participaçáo social na proteçáo da Política Nacional de Controle do Tabaco contra interferências indevidas, o que talvez seja o seu maior legado para as geraçóes presentes e futuras.

Essa data também foi a mola propulsora para o surgimento de outras importantes açôes no campo do combate ao tabagismo, como a instituição do Dia Mundial sem Tabaco, pela Assembleia Mundial de Saúde, em 1988; o lançamento, em 2007, do Global Adult Tobacco Survey (GATS), uma pesquisa de monitoramento do uso de tabaco em adultos implementada em 14 países e que no Brasil recebeu o nome de Pesquisa Especial de Tabagismo (PETab); as leis federais que instituíram restriçôes para as propagandas de cigarro, as advertências sanitárias nas embalagens dos produtos de tabaco e a proibição do fumo em ambientes fechados coletivos, entre outras, e a negociação do tratado internacional Convenção-quadro para o Controle do Tabaco (CQCT), apenas para citar algumas delas - todas devidamente retratadas em artigos desta edição.

No ano em que comemoramos o $25^{\circ}$ aniversário dessa Lei, esperamos que o Congresso Nacional mantenha, perante a sociedade brasileira, a evolução desse inabalável compromisso com a saúde e com a qualidade de vida da nação. E permita que, em setembro de 2011, durante a reunião de cúpula da Organização das Naçóes Unidas (ONU) sobre doenças crônicas não transmissíveis (DCNT), a delegação do Brasil possa sedimentar o caminho para que tenhamos a Copa do Mundo de 2014 sob a vigência de uma Lei Federal que o torna 100\% livre da fumaça de tabaco.

\section{Luiz Antonio Santini}

Instituto Nacional de Câncer 